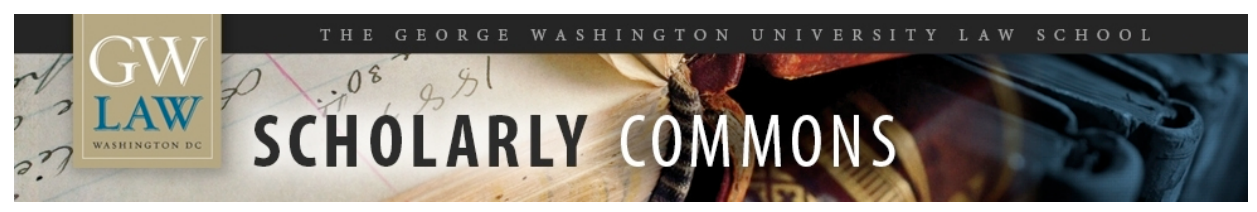

\title{
The Right to Strike and its Possible Conflict with Other Fundamental Rights of the People in the United States
}

Charles B. Craver

George Washington University Law School, ccraver@law.gwu.edu

Follow this and additional works at: https://scholarship.law.gwu.edu/faculty_publications

Part of the Law Commons

\section{Recommended Citation}

Charles B. Craver, The Right to Strike and its Possible Conflict with Other Fundamental Rights of the People in the United States at XX World Congress of Labour \& Social Security Law (Sept. 2012)

This Article is brought to you for free and open access by the Faculty Scholarship at Scholarly Commons. It has been accepted for inclusion in GW Law Faculty Publications \& Other Works by an authorized administrator of Scholarly Commons. For more information, please contact spagel@law.gwu.edu. 
THE RIGHT TO STRIKE AND ITS POSSIBLE CONFLICT WITH OTHER FUNDAMENTAL RIGHTS OF THE PEOPLE IN THE UNITED STATES

XX WORLD CONGRESS OF LABOUR \& SOCIAL SECURITY LAW (SEPT. 2012 SANTIAGO, CHILE)

CHARLES B. CRAVER, U.S. REPORTER FREDA H. ALVERSON PROFESSOR OF LAW GEORGE WASHINGTON UNIVERSITY LAW SCHOOL 


\section{DEFINITIONS}

“The term 'strike' includes any strike or other concerted stoppage of work by employees (including a stoppage by reason of the expiration of a collective-bargaining agreement) and any concerted slowdown or other concerted interruption of operations by employees.” 29 U.S.C. §142(2). [part of the Labor-Management Relations Act of 1947]

\section{LEGAL FRAMEWORK}

\section{(1)(a) Constitutional Provisions}

Although the First Amendment to the U.S. Constitution provides that "Congress shall make no law . . . abridging ... the right of the people peaceably to assemble, and to petition the Government for a redress of grievances," this provision has not been interpreted to guarantee private or public sector employees the right to engage in concerted work stoppages. United Federation of Postal Clerks v. Blount, 325 F. Supp. 879 (D.D.C.), affirmed, 404 U.S. 802 (1971). It merely protects the right of employees to form and join labor organizations and to seek favorable government laws and regulations.

\section{(1)(b) International Legal Protections}

Convention 87 of the International Labor Organization expressly protects the right of workers "to establish and ... to join organizations of their own choosing ...," and Convention 98 protects the right of workers to organize and to engage in voluntary negotiations with their employers. Although the United States has not formally ratified either of these Conventions, they define "core rights" which all ILO members are committed to following.

\section{(1)(c) Statutory Law and Regulations}

Private sector labor relations in the United Stages is regulated primarily through the National Labor Relations Act (NLRA). Section 7 of that enactment provides that "Employees shall have the right to self-organization, to form, join, or assist labor organizations, to bargain collectively through representatives of their own choosing, and to engage in other concerted activities for the purpose of collective bargaining or other mutual aid or protection, and shall also have the right to refrain from any or all of such activities ...” 29 U.S.C. § 157 . This provision affirmatively protects the right of employees to engage in work stoppages to further their economic interests. Employers are obliged to negotiate with labor unions selected by a majority of the workers in an appropriate bargaining unit, and it constitutes an unfair labor practice under 29 U.S.C. $\S$ 158(a)(5) for an employer to fail to bargain in good faith with such unions with respect to the wages, hours, and working conditions of such individuals. See 29 U.S.C. § 158(d). Where a majority of workers in a particular bargaining unit fail to select an exclusive bargaining representative, the employer may negotiate with unions on a members-only basis and apply the terms agreed upon only to such union members. The National Labor 
Relations Board has thus far indicated that such members-only arrangements are entirely voluntary and are not mandated by the NLRA.

Public sector labor relations is regulated for federal employees under Title VII of the Civil Service Reform Act of 1978. Under Section 7102 of that enactment [5 U.S.C. $\S$ 7102], federal workers have the right "to form, join, or assist any labor organization ...” and the right "to engage in collective bargaining with respect to conditions of employment through representatives chosen by employees . ..” Nonetheless, under 5 U.S.C. $§ 7311(3)$, individuals may not retain federal employment if they participate in any strike against their federal employer.

A majority of state legislatures have enacted laws providing state and local government employees with the right to join labor organizations and to bargain collectively with their government employers. Although a few of these states have authorized work stoppages by non-essential employees, most have expressly prohibited all strike activity. Such strike bans have been sustained when challenged on constitutional grounds. See generally H. T. Edwards, R. T. Clark \& C.B. Craver, Labor Relations Law in the Public Sector 617-725 (4 ${ }^{\text {th }}$ ed.1991).

Most public and private sector bargaining agreements contain grievancearbitration procedures which allow employees to file grievances challenging employer actions which might contravene contractual provisions. These agreements generally contain no-strike clauses prohibiting all work stoppages. Even where such contracts do not include express no-strike clauses, the U.S. Supreme Court has held that implied nostrike obligations are present with respect to contractual disputes subject to final resolution through exclusive grievance-arbitration procedures. Teamsters, Local $174 \mathrm{v}$. Lucas Flour Co., 369 U.S. 95 (1962). Although the Norris-LaGuardia Act deprives federal courts of jurisdiction to issue injunctions in cases involving labor disputes, they may enjoin strikes over issues subject to arbitral resolution. Boys Markets, Inc. v. Retail Clerks Local 770, 398 U.S. 235 (2970).

\section{(2) Positive Right to Strike}

As noted in Section (1)(c) above, the right to strike is expressly protected under Section 7 of the NLRA [29 U.S.C. § 157]. In addition, Section 13 of that enactment states that "nothing in this subchapter, except as specifically provided for herein, shall be construed so as either to interfere with or impede or diminish in any way the right to strike ...” [29 U.S.C. § 163]. Nonetheless, workers may only strike over mandatory subjects of bargaining - "wages, hours, and other terms and conditions of employment." While parties may lawfully bargain over other topics - "permissive” bargaining subjects - neither is legally obliged to do so. In addition, neither party may insist upon - or strike over - such permissive topics. If a labor union strikes over such non-mandatory subjects, it is guilty of bad faith bargaining in violation of Section 8(b)(3) [29 U.S.C. § 158(b)(3)]. In addition, the striking employees would be engaged in unprotected conduct and could be discharged. The same consequences would arise if a labor union demanded bargaining over - or struck over - an unlawful subject. 


\section{(3) Procedural Prerequisites}

Under Section 8(d) of the NLRA [29 U.S.C. § 158(d)], parties to an existing collective bargaining agreement cannot resort to a strike or lockout until they have endeavored in good faith to achieve a new agreement without a work stoppage. Sixty days prior to the termination date of the existing contract, the party wishing to negotiate a new agreement must provide the other party with notice indicating that they wish to modify the terms of employment. They must then provide the Federal Mediation and Conciliation Service and the relevant state mediation service with such notice thirty days prior to the termination date of the current contract to enable such agencies to offer the parties mediation assistance. Neither side may resort to a strike or lockout for sixty days after such notice has been provided to the opposing party (or the termination date of the contract, whichever comes later), to give the employer and the labor organization the opportunity to resolve their differences through the bargaining process. In the overwhelming number of cases, new agreements are reached through this process without resort to strikes or lockouts. Although many labor organizations conduct secret ballot strike votes prior to work stoppages, nothing in federal law requires them to do so.

States which permit public employees to strike, require negotiating parties to notify state mediation services and to accept mediator assistance before they cease to work. Relatively few public sector work stoppages occur in such jurisdictions.

\section{(4) Who Can Initiate Work Stoppages}

Under the NLRA, work stoppages may be initiated by employees acting alone or by their representative labor unions. NLRB v. Washington Aluminum Co., 370 U.S. 9 (1962), concerned a group of non-union employees who were dissatisfied with cold conditions at their place of work. When their employer failed to correct the situation, they walked off the job. Their concerted job action was found protected under the NLRA, even though they had no actual bargaining relationship with their employer. In most cases, however, work stoppages take place at facilities at which the employees are represented by bargaining agents. These labor organizations work to achieve new contracts through the bargaining process, and only resort to work stoppages as a last resort. Although they are not legally required to do so, most conduct closed meetings with the unit employees and explain the lack of progress at the bargaining table. They then conduct secret ballot strike votes. Even though such unions do not strike in the absence of positive votes, they almost always achieve such votes when the union leaders request them. Where public sector employees are permitted to strike, they also tend to conduct secret ballot strike authorization votes before they commence work stoppages.

\section{(5) Who May Participate in Strikes}

The primary group authorized to strike under the NLRA consists of members of the relevant bargaining unit. Under Section 7, they have the right to cease work or to refrain from such activity. In most cases, all of the bargaining unit members leave their 
jobs. On some occasions, however, some unit members elect to remain at work. If they return to work while actual members of the striking labor union, that organization may impose fines on them for failing to support their coworkers. NLRB $v$. Allis-Chalmers Mfgr. Co., 388 U.S. 175 (1967). On the other hand, if such persons are not union members or they resign from the union before they return to work, the labor organization may not impose such fines. NLRB v. Textile Workers, 409 U.S. 213 (1972).

Non-unit employees of the same employer may honor the picket lines of the striking workers in sympathy with them, unless such sympathy action is prohibited by their own bargaining agreement. A similar rule with respect to sympathy action applies to persons employed by secondary employers, even if they are covered by bargaining agreements containing no-strike clauses, unless such clauses expressly prohibit sympathy action at the premises of other employers. Even though such sympathy supporters tend to be in the same union as the strikers or in a different labor organization, non-union employees of other companies may honor the picket lines of the striking workers since they are considered to be engaged in "concerted activity" with the striking personnel within the meaning of Section 7 of the NLRA.

When secondary employees show up to make deliveries or to perform work at the premises of the struck employer, the striking employees may lawfully request that they do not cross their picket lines. International Rice Milling Co. v. NLRB, 341 U.S. 665 (1951). The striking individuals may not, however, ask such secondary sympathy strikers to cease doing work for their own employers anywhere else, since such conduct would violate the Section 8(b)(4)(B) ban on secondary activity [29 U.S.C. § 158(b)(4)(B)]. This critical difference concerns the fact that appeals to such secondary employees at the primary premises of the struck firm constitutes lawful "primary activity," while more expansive appeals that would affect neutral third parties constitute prohibited secondary conduct.

In many instances, the striking labor organization will contact other unions and ask that they instruct their members not to cross the picket lines of the strikers. Nonetheless, the strikers need not seek the formal support of other unions. When secondary employees show up at the struck premises, they may simply ask those individuals to support them by refusing to cross their lines.

Although strikes during the terms of existing bargaining agreements are rare, they constitute unprotected action if they contravene no-strike clauses contained in such agreements. Such actions do not constitute unfair labor practices, unless they occur during the last sixty days of existing contracts, in which case they would violate the Section 8(d) prohibition against work stoppages during those sixty day insulated periods. They would simply be considered unprotected, which would permit the affected employers to terminate their services. Such contractual disputes are expected to be resolved peacefully through established grievance-arbitration procedures.

As noted in (2) above, labor organizations may only strike over mandatory subjects of bargaining. If they strike over issues unrelated to wages, hours, and other 
terms and conditions of employment, they violate their duty to bargain and the actions of the striking employees would be unprotected. Political strikes would be similarly unprotected, since they would not involve mandatory bargaining subjects. While labor unions and their members enjoy a First Amendment right to petition the government for the redress of grievances, they cannot involve their employers in such controversies through strike actions.

Work stoppages are rarely used to enforce the provisions of existing bargaining agreements, because such controversies are generally subject to resolution through grievance-arbitration procedures. In fact, if workers strike over issues subject to arbitral resolution, they will be found to have breached their grievance-arbitration obligation and be enjoined.

Strikes occasionally arise over disputes between labor unions over the right to perform specific work which both entities believe should be assigned to members of their own bargaining unit. Once an employer assigns the work to the members of one unit, if employees in another unit strike, such jurisdictional disputes constitute a violation of Section 8(b)(4)(D) of the NLRA [29 U.S.C. § 158(b)(4)(D)]. When such a charge is filed with the Labor Board, if the disputing parties do not agree to resolve it themselves through tri-party arbitration, the Labor Board is obliged to determine under Section 10(k) [29 U.S.C. $§ 160(\mathrm{k})$ ] which group should be given the work in question.

(6) Restrictions on Strike Activity

\section{(a) \& (b) Strikes Over Issues Settled by Collective Bargaining or During Life of Bargaining Agreement}

Almost all bargaining agreements contain no-strike clauses prohibiting all work stoppages during the life of such contracts. Violations of such provisions constitute unprotected conduct, and may subject supporting labor organizations to claims for breach of contract. Even where no express no-strike provision is included in the contract, if workers strike over issues subject to final resolution through contractual grievancearbitration procedures, they would be in violation of the implied no-strike obligation emanating from those procedures. Teamsters, Local 174 v. Lucas Flour Co., 369 U.S. 95 (1962).

\section{(c) - (j) Scope of No Strike Duty}

Contractual no-strike obligations are binding on the parties to such agreements, but could theoretically be waived by the parties involved. It would be extremely rare for an employer protected by such a provision to authorize a work stoppage that would otherwise violate the no-strike duty. Most contracts contain both no-strike and no-lockout clauses, binding both the employer and the labor organization. Neither can generate a cessation of work without violating their obligation under such provisions. Such clauses cover all rights disputes which arise during the term of the contracts, including issues not specifically covered by the applicable contract. Labor organizations may not strike over 
issues included in management rights clauses, nor over disputes with other unions. In fact, if one union strikes over the assignment of work to members of another union, such conduct would contravene Section 8(b)(4)(D) of the NLRA which proscribes work stoppages over such jurisdictional disputes [29 U.S.C. § 158(b)(4)(D)]. Although political strikes are extremely rare in the U.S., due to the lack of influence by most employers over government policies, such work stoppages would almost certainly be found to violate contractual no-strike provisions. The same rule would apply to stoppages seeking to influence public opinions.

If either party violates a no-strike or no-lockout provision, the other may file a grievance claiming a breach of contract. If the matter is not amicably resolved by the parties themselves, it would be presented to an arbitrator who could direct the offending party to cease its improper actions. If that party refused to comply with the arbitral decision, the prevailing side could seek judicial enforcement of the arbitrator's award. If the losing party continued to ignore the judicially enforced arbitral directive, contempt sanctions would be imposed by the court involved.

Contractual no-strike duties continue for the life of the underlying agreements. In the U.S., most bargaining contracts are for one, two, or three years. Once they expire, the no-strike obligations cease to be effective. As long as the representative labor organization has given the employer at least sixty days notice of its desire to end the current agreement and to negotiate new terms and has given the appropriate federal and state conciliation services at least thirty days notice, it could engage in a work stoppage after the expiration date of the contract. Such work stoppages in support of bargaining over new agreements are perfectly lawful under the NLRA.

If employees decide to engage in a work stoppage in violation of a no-strike duty without the support of their union, they would be engaged in unprotected conduct and could be discharged. If their labor organization actually supported their conduct, it would be in breach of contract, and the employer could seek both a cease and desist order and damages through the grievance-arbitration procedures.

\section{(7)(a) Sympathy and Secondary Strikes}

Although sympathy strikes by employees of the struck firm who work in different bargaining units are likely to contravene no-strike clauses contained in their own bargaining agreements and thus constitute unprotected activity, sympathy action by individuals employed by secondary employers are usually lawful so long as such persons are merely asked to refrain from crossing the primary picket line at the premises of the struck company. If they are induced to cease work at any other locations, this would constitute unlawful secondary activity proscribed by Section 8(b)(4)(B) [29 U.S.C. $\S$ 158(b)(4)(B)].

Where goods are being delivered by employees of the struck employer, striking employees may follow the vehicles being driven by such persons and put up picket lines

at the premises of the firms to which they are making deliveries. To make such picketing 
protected primary activity, they must comply with rules established in Sailors' Union of the Pacific \& Moore Dry Dock Co., 92 N.L.R.B. 547 (1950). The primary employer must be located at the premises of the secondary employer; it must be engaged in its normal operations; the picketing must be limited to places reasonably close to the location of the primary situs; and the picket signs must disclose that the dispute is solely with the primary employer. Such picketers may even ask employees of the secondary employers not to load or unload the vehicles being used by the primary employer. They may not, however, induce such secondary employees to cease work on anything else. In addition, once the primary vehicle departs, the picketers must also leave the secondary premises.

Companies occasionally endeavor to limit the right of their own employees to appeal to persons employed by secondary firms by establishing separate gates to be used by such secondary personnel. If secondary employees using such separate entrances are coming to the primary premises to perform work related to the normal operations of the primary employer (e.g., picking up or delivering goods; performing maintenance work), striking employees of the primary employer may induce them to honor their picket lines. On the other hand, when such secondary workers are coming through the separate gates to perform tasks unrelated to the normal operations of the struck firm, the striking employees commit Section 8(b)(4)(B) violations if they induce them to cease work. International Union of Electrical, Radio \& Machine Workers, Local 761 v. NLRB, 366 U.S. 667 (1961).

Wholly secondary strike activity is expressly prohibited by Section 8(b)(4)(B) of the NLRA. As a result, if striking employees ask the employees of secondary employers who may be producing goods for the struck employer or who may be purchasing goods from that party to stop work on their own job functions, such conduct would constitute an unfair labor practice. In addition, it would subject the violating labor organization to liability for any damages caused to the primary or secondary companies under Section 303 of the Labor Management Relations Act [29 U.S.C. § 187].

When primary employers manufacture goods for sale by secondary retail establishments, striking manufacturing employees may go to such retail stores and put up picket lines, so long as they merely ask customers to refrain from purchasing goods that have been produced by the primary employer. Such conduct does not constitute proscribed “coercion” under Section 8(b)(4)(i). NLRB v. Fruit Packers [Tree Fruits], 377 U.S. 58 (1964). They may not ask customers not to shop at all at the retail stores while they carry goods manufactured by the struck firm, because such confrontational appeals are considered “coercive.” If the secondary store sells primarily goods produced by the struck firm, the picketers may not ask retail customers to refrain from such purchases, due to the fact such appeals would have a coercive impact due to the amount of business earned from such sales. NLRB v. Retail Clerks, Local 1001 [Safeco Title Insurance Co.], 447 U.S. 607 (1980).

If striking workers limit their activities at secondary retail establishments which carry items manufactured by their struck employer to handbilling, instead of picketing, they are allowed to request a total consumer boycott of those stores while they carry the 
struck goods. Edward J. DeBartolo Corp. v. Florida Gulf Coast Building Trades Council, 485 U.S. 568 (1988). The Supreme Court found that such peaceful handbilling did not constitute “coercion” under the NLRA.

Striking unions occasionally combine consumer picketing asking customers of retail stores not to purchase the struck products with consumer handbilling requesting a total consumer boycott of such stores. Unless the picketing and the handbilling take place in wholly separate locations, the Labor Board and the courts are likely to find that the more expansive handbilling appeal modifies the picketing appeal to make it broader than is acceptable, causing it to violate Section 8(b)(4)(i)(B). Boxhorn's Big Muskego Gun Club v. Electrical Workers, 798 F.2d 1016 ( $7^{\text {th }}$ Cir. 1986).

\section{(7)(c) \& (e) Slowdowns, Sit-ins \& Work-to-Rules}

Employees engaged in bargaining disputes with their employers may wish to exert economic pressure on their firms without walking out entirely. To accomplish this objective, they may slow down or work-to-rule. The Labor Board finds such activities to be unprotected, even though not unlawful, based upon the theory that employees owe a duty of loyalty to their employers. They may strike or they may work, but they may not receive full wages and deliberately fail to perform work at their normal levels. Elk Lumber Co., 91 N.L.R.B. 333 (1950). Courts have also found it unprotected for employees to request consumer boycotts of firm products while they continue to produce those items, again based upon the theory that it is unacceptable for them to continue to earn their wages while simultaneously injuring their employer economically. Hoover Co. v. NLRB, 191 F.2d 380 (6 ${ }^{\text {th }}$ Cir. 1951).

When employees go on strike, they may criticize the fact their employer has been unwilling to accept the terms begin demanded by their labor organization at the bargaining table, but they may not disparage the goods or services provided by their employer -- during or after the work stoppage. Patterson-Sargent Co., 115 N.L.R.B. 1627 (1956), concerned a paint company whose workers went on strike. The firm continued to operate with striker replacement workers. Striking individuals distributed handbills indicating that Pattern-Sargent paint was not being manufactured by the welltrained and experienced employees who have traditionally produced such paint, and warning potential consumers that paint being manufactured by the replacement workers might peel, crack, blister, scale, or otherwise fail to live up to the usual Patterson-Sargent paint standards. The Labor Board found that such product disparagement constituted unprotected behavior, due to the duty of loyalty owed by even striking employees toward their employer - even if the statements regarding the paint being produced during the work stoppage were accurate.

It is interesting to note the degree to which employees owe a duty of loyalty to their employers in the U.S., given the fact that employers owe their employees no reciprocal duty. Under the "employment-at-will" doctrine applicable to almost all private sector workers, employment relationships may be terminated by either party at any time for almost any reason. See M.A. Rothstein, C.B. Craver, E.P. Schroeder \& E.W. Shoben, 
Employment Law Treatise $\S 9.1$ ( $4^{\text {th }}$ ed. 2009). Protection against unjust and immediate dismissals tends to be available only where employment discrimination laws are being violated or the terminations are for reasons which contravene significant public policies. Id. §§ 9.9-9.13.

Sit-down strikes are unlawful in the U.S., based upon the fact that such activities violate trespasses laws. As a result, individuals who engage in such conduct may be immediately terminated, and may even be prosecuted for criminal trespass.

\section{(7)(f) \& (g) Blockades \& Picketing}

Employees engaged in labor disputes may lawfully picket their employer, with such action constituting classic concerted activity for mutual aid and protection within the meaning of Section 7 of the NLRA [29 U.S.C. § 157]. They may employ strong language critical of their employer, but, as noted above, they may not disparage the goods or services generated by their employer. They may ask persons who work for the struck employer and individuals working for secondary firms who are making deliveries to the struck facility to honor the picket lines. They may not, however, use threats of serious and immediate violence or engage in any violent behavior, since such conduct would violate Section 8(b)(1)(A) of the NLRA which makes it an unfair labor practice for a labor organization to restrain or coerce employees in the exercise of their protected rights [29 U.S.C. § 158(b)(1)(A)].

\section{(8) Strike Restrictions}

Federal employees may not strike. When thousands of federal air traffic controllers struck in 1981, President Reagan discharged them all. Although postal service employees are actually covered by the NLRA, instead of the provisions of Title VII of the Civil Service Reform Act, they are not permitted to strike. Individuals employed by most state and municipal governments may not strike. In the relatively few states which permit strikes by public employees, this right is only available to non-essential personnel. Police officers, firefighters, and emergency medical personnel may not conduct work stoppages.

Private sector employees are authorized to strike even when employed in critical industries. As a result, individuals who work for public utilities that are privately owned, as most are in the U.S., they may engage in work stoppages. Even persons who work for private health care institutions may strike, but they are required to provide their employers with at least ten days notice of any contemplated work stoppage [29 U.S.C. § 158(g)]. People who work for private defense contractors may also strike. Under the Labor Management Relations Act, if the President determines that a threatened or actual strike affecting an entire industry or part thereof would "imperil the national health or safety," he may instruct the Attorney General to seek an eighty day injunction against such action to allow an emergency board to conduct a fact finding hearing and report on the final positions of the parties [29 U.S.C. §§ 176-180]. During the last twenty days of that court order, the Labor Board must conduct a secret ballot vote among the workers on the employer's final bargaining proposal. If the voters reject that offer, the injunction 
must expire, and the employees may engage in a work stoppage. Under the Railway Labor Act, which governs railroad and air line personnel, if the National Mediation Board determines that a dispute "threatens substantially to interrupt interstate commerce to a degree such as to deprive any section of the country of essential transportation services," it may notify the President who may authorize judicial action to enjoin the stoppage for sixty days while a board conducts hearings and recommends settlement terms which the parties are not obligated to accept [45 U.S.C. § 160]. Once the sixty day injunctive order has expired, the employees may strike.

\section{(9) Other Limits to Lawful Strikes}

U.S. laws do not impose strike limitations based upon abuse of rights, fairness, reasonableness, or other similar concepts. Except for the previously mentioned ability of the President to seek eighty day injunctions for strikes which imperil the national health or safety or sixty day injunctions for strikes by airline or railroad workers which would disrupt services to regional areas, there are no laws or policies which restrict work stoppages based upon the need to protect the common good. The Labor Board is not empowered to determine whether union bargaining demands are excessive or employer offers are parsimonious. As a result, strikes do not lose their protection because the union bargaining position is unreasonable, nor do those job actions obtain a greater degree of protection if employer offers are unduly minimal. Even when a labor organization decided to strike a trucking firm to drive it out of business because of a previous organizing fight the union had with that company, the Supreme Court held that the union was exempt from antitrust liability based upon a provision in the Clayton Antitrust Act which exempts labor organizations from antitrust liability. Hunt v. Crumboch, 325 U.S. 821 (1945).

\section{(10) Lawful Strike Protections}

Individuals who engage in lawful strikes are protected from employer discipline under Section 7 of the NLRA [29 U.S.C. § 157]. If an employer discriminates against such strikers, it commits an unfair labor practice under Section 8(a)(1), which prohibits discrimination against persons who have engaged in protected concerted activity [29 U.S.C. $§ 158(a)(1)]$. Since Section 7 also protects the right of employees to refrain from such concerted activity, if they refuse to participate in a work stoppage or decide to return to work during a strike, the union involved may not discipline them - unless they remained union members at the time they crossed the picket lines and went to work. It is thus critical for such persons to resign their membership before they engage in such actions.

Persons who go on strike are not entitled to any pay during the time they are out of work. In almost every state, they are also ineligible for unemployment compensation benefits due to the fact their temporary loss of work is due to a labor dispute. See M.A. Rothstein, C.B. Craver, E.P. Schroeder \& E.W. Shoben, Employment Law Treatise § 10.14 ( $4^{\text {th }}$ ed. 2009). If an employer is forced to lay off other employees due to an on-

going work stoppage, those individuals also lose their right to wages. On the other hand, 
if they are in no way connected with the labor dispute, they may obtain unemployment benefits for the period of their unemployment.

The Supreme Court has held that persons who engage in economic strikes designed to advance bargaining interests may be temporarily or permanently replaced by their employer for the purpose of continuing business operations. NLRB v. Mackay Radio \& Telegraph Co., 304 U.S. 333 (1938). An employer may not terminate the persons who struck, since they were engaged in protected activities, but it need not allow them to return to work as soon as the stoppage has ended. It may instead retain the replacement workers. Trans World Airlines., Inc. v. Independent Federation of Flight Attendants, 489 U.S. 426 (1989). The replaced strikers retain their "employee" status and must be placed on preferential recall lists. Laidlaw Corp., 171 N.L.R.B. 1366 (1968). As their prior positions become vacant, they must be recalled ahead of new job applicants.

\section{(11) Illegal Strikes and Liability}

Work stoppages may be unlawful either because they contravene no-strike provisions in bargaining agreements or because they violate provisions of the NLRA. If an employer contends that a labor organization has breached the no-strike clause by supporting an improper stoppage, it would normally file a grievance and take the matter to arbitration. The arbitrator would hear the case, and order the workers and the union to cease their concerted activities if a breach of contract was found.

Certain work stoppages constitute unfair labor practices under the NLRA. When issues of this type are raised, the adversely affected employer must file an unfair labor practice charge with the Labor Board. It then conducts a hearing to determine if a violation has occurred. If the labor organization is using the stoppage to obtain a "hot cargo" agreement under which this employer would agree to cease doing business with other firms involved in labor disputes with their unions or that do not have bargaining relationships with unions, such action would violate Section 8(b)(4)(A) [29 U.S.C. § 158(b)(4)(A)]. If the strike impermissibly induces secondary employees to cease doing work on anything but the primary premises, this would contravene Section 8(b)(4)(B) [29 U.S.C. § 158(b)(4)(B)]. If the strike is designed to force the target employer to recognize this labor organization as the representative of its employees where another union has been certified as the bargaining agent of those workers, such action would violate Section 8(b)(4)(C) [29 U.S.C. § 158(b)(4)(C)]. If the strike was designed to force the employer to assign work to the members of this union which was given to other employees, such action would violate Section 8(b)(4)(D) [29 U.S.C. § 158(b)(4)(D)]. If any such violations were involved, the Labor Board would be obliged to petition a District Court for an injunction ending the impermissible stoppage [29 U.S.C. § 160(l)]. Although the Labor Board may ultimately order the responsible labor organization to refrain from such conduct in the future, it does not have the authority to impose any fines on such entities. Any primary or secondary employers injured by violations of Section 8(b)(4) may seek actual damages in proceedings in District Court under Section 303 of the Labor Management Relations Act [29 U.S.C. § 187]. 
Under Section 8(b)(7) of the NLRA [29 U.S.C. § 158(b)(7)] it is an unfair labor practice for a labor organization to strike and picket an employer seeking recognition as the bargaining agent of employees where: (A) the employer has lawfully recognized another union and a question of representation may not currently be raised under the statute; (2) where during the prior twelve months a lawful representation election has been conducted; or (3) where such actions continue for more than thirty days without a petition for a Labor Board election being filed. If the Labor Board believes that violations of this section have occurred, it is similarly obliged to petition a District Court for an injunction ending the union's unlawful activities. No fines or monetary relief is available with respect to violations of Section 8(b)(7).

Labor organizations guilty of violating Section 8(b)(4) or 8(b)(7) cannot have their representational rights withdrawn, nor may responsible union leaders be fined or punished criminally. The right of unions to collect dues from bargaining unit members continues despite any such violations.

When individual employees engage in a strike which violates the no-strike clause in a bargaining agreement or which constitutes an unfair labor practice under the NLRA, they are involved in unprotected conduct. As a result, they can be disciplined by their employer. They cannot be held liable for unfair labor practices, however, since only labor organizations can be held responsible for such behavior. If their actions contravene the provisions of their collective contract, they could conceivably be sued for breach of contract damages, but such actions are rare due to the fact that most employees lack the financial resources to cover any amounts that might be awarded.

\section{(12) Arbitration}

In the U.S., we distinguish between rights arbitration, which involves claims arising under the provisions of existing bargaining agreements, and interest arbitration, which concerns the terms which should be included in future bargaining agreements. When grievances are filed alleging violations of the terms contained in current contracts, the parties may take the matters to arbitration if no mutual resolutions are achieved. If the offending party refuses to participate in an arbitral proceeding, the petitioning party may ask a District Court to direct participation under Section 301 of the Labor Management Relations Act [29 U.S.C. § 185]. Arbitrability of such disputes is assumed, and a court will only refuse to direct arbitration where it is clear that the dispute is not covered by the applicable grievance-arbitration procedures.

Private sector interest arbitration over the terms to be included in future contracts is rare in the U.S. When negotiating parties are unable to achieve mutual accords, the dissatisfied union must either accept the employer's proposed terms or engage in a work stoppage. The bargaining parties may agree to submit their controversy to arbitration for final resolution, but such action is most unusual. The parties must mutually agree upon the arbitrator(s) to resolve their dispute. No government agency possesses the authority to direct such arbitral proceedings. Arbitral awards issued by such neutrals are binding on the submitting parties, unless some clear procedural error can be established. 
Binding interest arbitration is required under a number of state public bargaining laws as a substitute for the right of government employees to strike. If bargaining parties have difficulty achieving new contracts, mediator assistance is usually required. If such assistance is unsuccessful, the parties may be required to submit their dispute to arbitration. The applicable public sector labor relations board is likely to appoint the persons who will serve as arbitrators. In most cases of this kind, the arbitration panel must select between the final offers of the government employer and the representative labor organization. This may be done on a complete package basis, in which case the arbitrators must either accept the entire employer proposal or the entire union proposal. It is more common for arbitration panels to resolve such matters on an issue-by-issue basis. It considers each bargaining topic separately and chooses the one it considers to be more reasonable. Although limited judicial review is available with respect to such arbitral awards, the decisions by such panels are usually accepted by reviewing judges.

\section{STRIKES IN PRACTICE}

Strike activity in the U.S. has declined substantially over the past several decades for several reasons. First, the percentage of private sector workers represented by labor organizations has declined. In the late 1950s. 35 percent of such individuals were union members. By the end of 2010, that rate had declined to 6.9 percent. Union Membership Dropped in 2010, as Key Industries Shed Jobs, DAILY LABOR REPT. (BNA) No. 14 (Jan. 21, 2011), at AA-1. [36.2\% of government employees are still union members] Second, the economic crisis of the past several years has caused representative unions to lower their sights and accept less generous wage increases without resort to work stoppages. Although the vast majority of new bargaining agreements have traditionally been achieved without work stoppages, this has become especially true in recent years.

It is rare for labor organizations and employees to engage in unlawful strikes. In the rare occasions in which they strike in violation of the NLRA, the expeditious issuance of District Court injunctive orders has ended such conduct without the need for employers to terminate such persons. Stoppages in violation of contractual no-strike clauses have similarly been rare. As a result, few individuals have been discharged for such behavior.

Although employers possess the right to hire permanent replacements for economic strikers, most firms have not done so. Such work stoppages do not usually continue for prolonged periods, and struck firms either accept the shut downs or operate with managers performing rank-and-file work. It is difficult for firms to locate persons who are willing to cross picket lines and who possess the skills necessary for them to move into striker positions and immediately perform their job tasks efficiently.

The common reason for work stoppages in the U.S. involves conventional bargaining disputes. Rarely do such strikes pertain to other matters. In most cases, negotiating parties are able to achieve new agreements through the bargaining process, with or without mediator assistance, rendering strike activity unnecessary. Even when 
stoppages do occur, they are usually over within a week or two. This area is left almost entirely unregulated. The parties are obliged to bargain over wages, hours, and working conditions, and the Labor Board possesses no authority to tell employers and unions what they should accept. When stoppages do occur, the Labor Board may not determine whether the union position is reasonable or unreasonable.

Public sector strikes in states which authorize such activities tend to be relatively rare, since most bargaining parties are able to achieve new agreements without resort to such disruptions. Strikes in states which prohibit such actions are even rarer. When they do occur, they are likely to be enjoined by courts quickly. Unions that ignore such court orders are likely to sustain substantial contempt fines.

General strikes are unheard of in the U.S. Almost all work stoppages involve the parties directly involved in the bargaining process. Unlike other countries in which national stoppages take place either for political purposes or to support particular workers, such actions almost never occur. Sympathy strike activity by the coworkers of employees engaged in a work stoppage may take place, and the employees of secondary employers may honor the primary picket lines of striking personnel. More expansive strike activity is relatively nonexistent.

When major labor unions seek the assistance of other unions and/or the general public when they are endeavoring to organize the workers of particularly anti-union firms, they may ask such persons to boycott products or services provided by the target companies. This approach was successfully employed by the United Farm Workers Union when they sought to organize agricultural employees. They requested grape and lettuce boycotts, which put significant pressure on the growers being affected.

Relatively expansive pro-union demonstrations were conducted in Wisconsin during the spring of 2011, when the newly elected Governor decided to significantly curtail the bargaining rights of state employees. Smaller demonstrations also occurred during the same time frame in Ohio, when its Governor sought to reduce the bargaining rights of public sector workers. In neither case, however, did the employees refuse to perform their regular jobs.

\section{SUPPORT OF STRIKING WORKERS}

Noninvolved labor organizations tend to support striking workers in either of two ways. They frequently ask their members working for secondary employers to honor the picket lines established by the striking workers. Such sympathy activity can enhance the economic impact of the work stoppage on the struck firms. They may also provide monetary support to enable striking unions to extend benefits to individuals who are out of work. These may be outright grants or temporary loans.

Employees engaged in work stoppages are disqualified from unemployment benefits in all fifty states. See M.A. Rothstein, C.B. Craver, E.P. Schroeder \& E.W. Shoben, Employment Law Treatise $\S 10.14$ ( $4^{\text {th }}$ ed. 2009). In almost all of these states, 
striking individuals are ineligible for benefits for the entire time they are out of work. Only in New York State is the disqualification period of shorter duration. After seven weeks of unemployment, striking employees in New York may apply for benefits. In the twenty-two states which disqualify people whose unemployment is due to a "stoppage of work due to a labor dispute," if their employer either continues to operate or subsequently reestablishes operations, striking individuals can often receive benefits due to the absence of any "stoppage of work."

\section{ECONOMIC RELEVANCE}

The U.S. labor force currently consists of about 154 million persons. The statistics contained in the following table taken from the U.S. Department of Labor Bureau of Labor Statistics demonstrate the relatively small impact of strike activity on the U.S. economy [http://www.bls.gov/news.release.wkstp.t01.htm].

\section{Table I. Work Stoppages Involving 1000 or More Workers}

$\begin{array}{lrcc}\text { Year } & \text { No. of Stoppages } & \text { No. of Wkrs. Involved } & \text { \% Wk. days Lost } \\ 1950 & 424 & 1,698,000 & 0.26 \% \\ 1960 & 222 & 896,000 & 0.09 \% \\ 1970 & 381 & 2,468,000 & 0.29 \% \\ 1980 & 187 & 795,000 & 0.09 \% \\ 1990 & 44 & 185,000 & 0.02 \% \\ 2000 & 39 & 394,000 & 0.06 \% \\ 2010 & 11 & 45,000 & <0.005 \%\end{array}$

Strikes by public sector employees are relatively rare. Of the fifty states, twentysix have expansive bargaining rights for their employees, and another nine have extended bargaining rights to specific groups of government personnel (e.g., school teachers). [See M.H. Cimini, "1982-97 State and Local Government Work Stoppages and Their Legal Background,” 3 Compensation and Working Conditions 32 (Fall 1998). By the mid1990s, ten states had granted the limited right to strike to state employees, with none authorizing stoppages by such essential personnel as police officers, firefighters, and emergency medical personnel. Between 1982 and 1997, there were a total of 116 work stoppages by public employees, involving a total of 627,750 strikers. Id. at 34 . The two states which had the greatest number of government strikes during that period were California with 25 and Michigan with 15.

Due to the relatively short duration of most private and public sector work stoppages in the U.S., the inconvenience to the general public is minimal. When specific private sector firms are shut down, consumers are able to obtain similar goods and services from competing companies. Although public sector strikes do inconvenience persons who require government services, they are usually able to get the assistance they need within a few days or, at most, several weeks. 


\section{LEGAL PROTECTION OF CONFLICTING INTERESTS}

Struck employers cannot seek judicial or Labor Board orders ending strikes merely because they may inhibit their ability to provide their usual goods or services. They may, however, hire temporary or even permanent replacements for the striking personnel. NLRB v. Mackay Radio \& Telegraph Co., 304 U.S. 333 (1938). They may also allow bargaining unit members to cross picket lines and return to work. Trans World Airlines. Inc. v. Independent Federation of Flight Attendants, 489 U.S. 426 (1989). They may bring in replacement workers from temporary employment agencies. Strikers who are temporarily replaced can return to work as soon as their union decides to end the work stoppage. Strikers who are permanently replaced must be placed on preferential recall lists and must be rehired when their former positions become vacant. Laidlaw Corp., 171 N.L.R.B. 1366 (1968). If striking employees make it difficult for firms to continue to operate, they may lay off their non-striking workers until they are able to resume normal operations. Such laid off individuals may apply for unemployment compensation, but they have no legal right to demand that their employers continue to employ them during the strikes by their fellow workers.

When employers fear that their employees may walk out at particularly critical times, they may use preemptive defensive lockouts to avoid such difficulties. Betts Cadillac-Olds, Inc., 96 N.L.R.B. 268 (1951). In addition, they are permitted to use offensive lockouts simply to put pressure on workers and their representative unions at the bargaining table. American Ship Building Co. v. NLRB, 380 U.S. 300 (1965). Nonetheless, it is quite rare for employers to employ defensive or offensive lockouts, due to the fact that the vast majority of bargaining agreements are achieved today without any work stoppages. When employees are locked out, they are not entitled to continued pay.

Once a work stoppage begins, employers may insist that striking workers leave their premises. If they fail to do so, they violate state trespass laws. Local police officers can be asked to escort them off the company property.

\section{NEUTRALITY OF THE STATE}

Although the federal government has provided private sector workers with the right to engage in collective bargaining and the right to strike under the NLRA and the Railway Labor Act and a majority of state governments have extended bargaining rights to public sector personnel, government entities remain neutral during labor disputes. They support neither the struck employers, nor the striking employees. They frequently provide mediator assistance to such parties, but such neutral bargaining facilitators must be careful not to support the positions taken by either side. Even in the rare situations in which the President declares a national emergency dispute and seeks a temporary restraining order against strike activity, the President does not personally support either side. In addition, presidential boards established to conduct fact-finding hearings with respect to such emergency disputes must maintain their professional neutrality. They may endeavor to encourage the parties to resolve their bargaining differences, but they do not support either side. 


\section{PARITY OF PARTIES}

There is no policy in U.S. labor relations law which endeavors to place bargaining parties on an equal footing. It is often said that under the basic rule of collective bargaining, to the lion goes the lion's share. It labor unions and their members possess the economic power to demand generous wage increases and expansive fringe benefits, they may obtain such terms. On the other hand, if employers possess the power to grant their employees minimal - or even no - wage and benefit increases, they may be so parsimonious. This is true even when the employers in question are doing well financially. There is no rule of law which requires them to share their gains with their employees. 